\title{
İzleyicinin Değișen Konumu: Katılımcı Sanat Pratikleri ve İktidarın Paylaşımı
}

\section{Changing Position of the Audience: Participatory Artworks and Sharing of the Power}

\section{Özüm Koșar}

Arş. Gör., Ankara Hacı Bayram Veli Üniversitesi Güzel Sanatlar Fakültesi Resim Bölümü email: ozum.kosar@hbv.edu.tr (DORCID ID: https://orcid.org/ 0000-0002-2507-831X

iThenticate' Bu makale bilimsel etik ve kurallara uygun hazırlanmış ve intihal incelemesinden geçirilmiștir

Atıf (APA 6)/To cite this article

Koşar, Ö. (2020). İzleyicinin değişen konumu: Katılımcı sanat pratikleri ve iktidarın paylașımı. Atatürk Üniversitesi Güzel Sanatlar Enstitüsü Dergisi, 26(44), 170-180. doi: https://doi.org/10.35247/ataunigsed.672128

Makale Gönderim Tarihi/Received: 08/01/2020

Makale Kabul Tarihi/Accepted: 13/03/2020

Makale Yayın Tarihi/Published: 19/03/2020

Review Article / Derleme Makalesi

\section{Öz}

Hazır-nesne fikrinin tartışmaya sokulması ve sanat-hayat arasındaki sınırların belirsizleş(tiril)mesi, izleyicinin konumunu sorgulatmıș; sanat yapıtıyla arasındaki mesafeyi muğlaklaştırmıştır. Bu bağlamda, sanat yapıtı ile izleyici arasında dönüşüme uğrayan bu ilişki, katılımı merkezine alan yeni bir sanat üretimini güdülemiştir. 1990'lardan sonra örnekleri gittikçe yaygınlaşan bu izleyici odaklı sanat pratikleri, özellikle modern sanatın izleyiciyi edilgenleștirici tavrı yerine özgürlükler tanıyan, kimi zaman da doğrudan seyircinin katılımıyla gelişen yeni bir anlayışı ortaya koymaktadır.

İzleyicinin katılımıyla zenginleşen bu yeni sanat anlayıșı, onu pasif konumdan eyleyen konuma sokarak, sanatı hayatla ilintili bir edime dönüştürmüştür. Katılımcı sanat pratikleri, izleyicisini alışılagelmiş durağan formundan uzaklaştırarak bireyler için yeni bir karşılaşma alanı sağlamaktadır. Özellikle günümüzde bireyselleşmenin artan ivmesine karşı katılımcı sanatın gerçekleştirdiği "bir aradalık" fikri, örtük bir toplumsal misyon gibi sanat yoluyla sosyalleşmenin ortamını uygunlaştırmaktadır. $\mathrm{Bu}$ bağlamda, kolektif bir bilinç meydana getiren katılımcı sanat etkinlikleri, daha önce yolları kesişmemiş kişileri ortak bir paydada toplamanın kültürel yordamı olma eğilimi göstermektedir. Bu yazının genel kapsamı, izleyicinin değişen sanat perspektiflerine göre nasıl konumlandığını ve güncel sanat anlayışında eyleyen izleyicinin sanat pratiklerine nasıl yansıdığını irdelemektir.

Anahtar kelimeler: İzleyici ve Sanat, Katılımcı Sanat, İnteraktif Sanat, İlişkisel Sanat

\begin{abstract}
The discussion of the idea of ready-made and the uncertainty of the boundaries between art and life questioned the position of the audience; the distance between the work of art has blurred. In this context, this relationship, transformed between the work of art and the audience, motivated a new art production that focused on participation. These audience-oriented (interactive) art practices, whose examples have become more widespread after the 1990s, reveal a new understanding that gives freedom to the audience, rather than the passive attitude of modern art.

This new understanding of art, enriched with the participation of the audience, has transformed it from a passive to an active position and transformed art into a life-related act. Participatory (interactive) art practices provide a new meeting space for individuals by moving their audience away from their usual static form. In spite of the increasing momentum of individualization, the idea of a "togetherness" realized by the participatory art, especially as an implicit social mission, harmonizes the environment of socialization through art. In this context, participatory art activities that create collective consciousness tend to be the cultural procedure of bringing together people who have not crossed paths on a common ground. The general scope of this article is to examine how the audience is positioned according to the changing art perspectives and how the audience who is acting in contemporary art is reflected in the art practices.
\end{abstract}

Keywords: Audience and Art, Participatory Art, Interactive Art, Relational Art

\section{Giriş}

Sanat, en erken örneklerden bu yana insanlar-arası iletişimin temelini oluşturmaktadır. Mağara duvarı, bir kanvas üzerine ya da kolektif bir sürecin ürünü olması bu en temel insani ihtiyacı değiştirmemiş, çeşitli tarihsel görüşler bazında zaman zaman örtükleşse de doğası gereği bir mesaj iletme özelliğini hep sürdürmüştür. Bu çalışma bu görüşten hareketle, sanat-sanat yapıtt-izleyici arasında oluşan üçgende güncel sanat dinamiklerini incelemekte ve modern sanat anlayışındaki sanatçı temelli görüşün değişimi üzerinden ilişkisel estetiği konumlandırmayı hedeflemektedir. Postmodern dönemeçle birlikte bakışta yaşanan dönüşüm, sanat ile hayat arasındaki sınırların eritilmesi açıdan oldukça önemlidir ve katılımeı sanat fikrini olumlu yönde etkilemiştir. 1990'lı yıllarla birlikte bu katılımcı pratikler, teorik tartışma alanlarından da aldığı itkiyle önemli bir boyut kazanmıştır. Araştırma kapsamında, Jacques Rancière, Brian O’Doherty, Donald Kuspit, Walter Benjamin, Nicolas Bourriaud gibi önemli düşünürlerin görüşlerine başvurulmuş, öncelden güncele birçok sanatçı üzerinden örnekler verilmiştir. 


\section{Yöntem}

$\mathrm{Bu}$ araştırma, güncel sanatın sanat=hayat odaklı görüşü üzerinden izleyicinin konumuna ilişkin değişimin ve yapıtın bu değişen görüş ile birlikte edindiği yeni anlamların irdelendiği nitel bir araştırmadır. Çalışma kapsamında konu ile ilgili literatür taraması yapılarak veri toplanmış ve derlenen veriler ışığında katılımcı sanat pratikleri incelenerek söz konusu etkileşim sürecinin yapıtlar ve sanat üzerindeki iktidar konumlarını nasıl değiştirdiği örneklerle tartışmaya açılmıştır.

\section{3. İzleyicinin Kimliği}

Ne yapmak istediğini o (Sanatçı) bilir, biz bilmeyiz; ne yaptığını biz biliriz (İzleyici), o bilmez.

Jean-Paul Sartre

İzleyici, sözcük olarak dilimizde "izleme işini yapan kişi” olarak tanımlanmakta (“TDK”, t.y.), bir sanat yapıtına karşı "izleme işini yapan kişi”" için de benzer bağlamda "izleyici, seyirci, alımlayıcı" gibi terimler kullanılmaktadır. Peki, kimdir bu izleyici? Postmodern kırılmaya kadar durağan pozisyonda karşımıza çıkan bu kişi, uzunca bir süre sanat yapıtının sınırlarına saygılı-mesafeli bir yan karakter olmuştur. İzleyici, modern paradigmanın sanatçı ve sanat yapıtını altın harflerle konumlandırdığı sahnenin en ücra köşesinde bırakılmış kişidir. Rancière'e göre, bir görünüşün karşısına geçen ama o görünüşün üretim sürecini veya gizlediği gerçekliği bilmeyen; eylemenin zıddı olan bakmak fiilinden meshul; edilgen ve hareketsiz; hem bilmek kabiliyetinden hem de eylemek kudretinden kopmuş bir bireydir (Rancière, 2009, s. 10). Yani izleyici, modern sanat boyunca sanat yapıtına karşı belli bir mesafeyi gözeten, işin içine mümkün mertebe dahil olmayan bir duruş sergilemiştir. Sanatın yüceliğini vurgulayan böylesi bir anlayışta önemli olan, sanatçının elinden çıkmış yapıttır. İzleyici ise dehayı alkışlayan ve tereddütsüz destekleyen, isimsiz bir figüran muamelesi görmektedir.

Doherty’e göre zaman içinde karmaşık roller arasında kalan izleyici, motor refleksler yığınına dönüşmüş, karanlığa alışmış bir gezgin olarak tablodaki hareketli unsur, bir sahte aktör, hatta sanatla mayınlanmış arazideki bir ses ve 1ş1k dürtüsü haline gelmiştir (O'Doherty, 2013, s. 59). Uzun süre boyunca bu sabit konumu sürdüren izleyici, Romantik sanat anlayışı ile birlikte bir miktar belirginleşmiş ve "bakan göz" ile simgesel bir değiş tokuş içine girmiştir. "Sabit-durağan izleyici" yerini “çeşitli farkındalıklar kuşanmış göz”e bırakmıştır. Göz, izleyici'ye kıyasla daha eğitilebilirdir ve estetik olarak geliştirmiş olduğu bir bilinç söz konusudur, fakat aslında gözün sahip olması varsayılan bu bilinç deha nesnesini daha da parlatmak için yalnızca bir yöntemdir. Ne de olsa, bilgi sahibi izleyicinin gözü ve onun alımladığı yapıt çok daha önemlidir.

\section{Bakıştaki Dönüşüm}

Sanat-izleyici arasındaki sınırlar ve sorgulamalar düşünüldüğünde, sanatın korunaklı alanlarına dokunmak isteyen Dada bir başlangıç noktası olarak kabul edilebilir. Nitekim, Aydınlanma ve Modernizm'in getirisi olan "yüce sanat" anlayışı bu dönemde sorgulanmaya ve eleştirilmeye başlanmış, büyük harflerle bahsi geçen "Sanat" artık aurasını kaybederek, hayatla bir anılmaya başlanmıştır. Auranın kaybolması sanat yapıtı ile izleyici arasındaki mesafeyi yok eder. Dünya savaşlarının toplumsal olarak yarattığı sarsıntı ve yaşanılan birçok değişim-dönüşümbunalımdan etkilenen Dadacılar, modern paradigmada önemsenen her bir değeri altüst etmiş, sorgulamaya açmıştır. Auranın kaybı ise Dada sanatçılarının bilinçli olarak yaptığı bir şeydir. Dadacıların, "amaçladıkları ve gerçekleştirdikleri şey, yaratımların aurasını acımasızca yok etmektir (...) 'Sanatın genel doğası'ndaki değişim, burada artık teknolojik yeniliklerin sonucu değil, yeni bir sanatçı kuşağının bilinçli davranışı dolayımıyla gerçekleşmektedir (Benjamin, 2007, s. 74). Örneğin, 1920'de Köln'deki 2. Dada gösterisinde, Max Ernst, izleyiciyi katılıma teşvik edecek bir imkân sağlamıştır. Ernst, geleneksel yollarla yapılmış bir ahşap heykeli istenildiği taktirde parçalanması için bir balta ile sergileyerek, izleyicileri bu heykeli baltayla yok etmesi için provoke etmiştir. $\mathrm{Bu}$ eylem gerçekleştiği takdirde hem tarihsel değerlere bir baş kaldırı hem de izleyicinin sınırsızlığına bir vurgu yapılmış olacaktır. Benzer olarak 1913'te "Tabure Üstünde Tekerlek" çalışmasını gerçekleştiren Marcel Duchamp da izleyicinin yapıtı eğlence için bile olsa döndürmesini arzulamıştır. Burada izleyicinin katılımına açılan yapıtlar ile birlikte, öncesinde bir görgü kuralı sayılan "sanat yapıtına dokunulmaz" düşüncesi de hiçe sayılmış, dokunulan, etkileşime geçilen yeni bir sanat fikri ortaya konmuştur. 


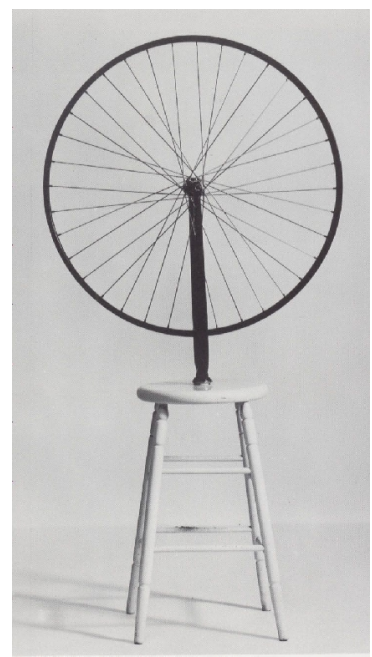

Görsel 1. Marcel Duchamp, Bisiklet Tekerleği (Bycle Wheel), 1913

Umberto Eco'ya göre nesnel bir veri olan "yapıt" ile onu "alımlayan özne" arasındaki etkileşim kaçınılmazdır. Üretim ile tüketimin birbirine yabancı iki nesnenin kökeninde bulunabileceği bir gerçektir; ama, üretici bir işlem (dolayısıyla bir nesne, bir yapıt) tasarladığı anda, sanatçının ayrıca bir tüketim tipini tasarladığı da yine bir gerçektir (Eco, 1992, s. 9). Başka bir deyişle, yapıt sanatçısı tarafından üretilmiş bir nesne olduğu kadar, izleyicisi tarafından tüketilen ve böylelikle tekrardan gerçekleşen bir yapıya da sahiptir. Nitekim, yapıtın oluşum sürecini psikanalitik bir seansa benzeten Duchamp da, sanatçının sanat yapıtının oluşumunda son nokta olmadığını savunmaktadır. Ona göre, sanatçının kendi duygulanımlarını ve düşüncelerini aktardığı bir nesne olan sanat yapıtının izleyici tarafından süzgeçten geçirilmesi gerekmektedir. İzleyicinin görevi yapıtın estetik ölçülere göre ağırlı̆̆ını saptamaktır; izleyici yapıtın içsel niteliklerini ortaya çıkarıp yorumlayarak dış dünyayla bağlantısını sağlar, böylece yaratma edimine katkıda bulunmuş olur (Kuspit, 2010, s. 34). Duchamp burada söz konusu bu katkının nihai nokta olmadığı konusunda da bir vurgu yapmaktadır. Çünkü daha sonrasında eleştirel yeni tepkilerle yapıtın yaratıcı transferi devam edecektir. Yorumun sonsuz döngüsü yapıtı izleyicisine göre yeni baştan gerçekleşen bir etkinliğe dönüştürmektedir. Sanat yapıtı, sanatçıyla iletişim kurmak için bir araç, izleyicinin bu iletişim yoluyla, sanatçıyla ve onun yaratıcı edimiyle sihirli bir biçimde özdeşleşmesini sağlayan bir ayindir (Kuspit, 2010, s. 35).

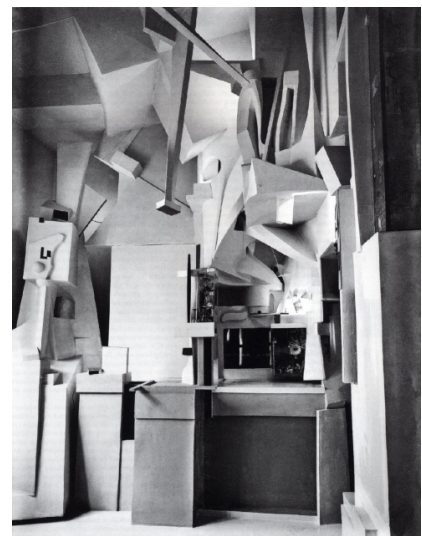

Görsel 2. Kurt Schwitters, Merzbau, 1933

İzleyiciye dair bakışı kıran erken örneklerden bir diğeri ise Kurt Schwitters'in 1923'te Hanover'da yaptı̆̆ı, 1943'te yıkılan Merzbau'sudur. Daha önceleri galeri mekânında durağan biçimiyle sergilenmesine alışılan sanat yapıtı, Merzbau'yla kucaklayıcı bir mağaraya dönüşmüştür. İzleyicisinin karşısında dikilmekten ziyade onu içine alma eğilimi gösteren bu yapı, deneyimi hissetmek adına girift birçok şeyi içinde barındırmaktadır. Dada ile Konstrüktivizm, yapı ile deneyim, organik ile arkeolojik, dışardaki kent ile içerdeki mekân arasında gidip gelen diyalektiği, aslında tek bir yapıt etrafında döner: bu, dönüşümdür (O'Doherty, 2013, s. 63).

John Cage'in ses getiren 4'33' "adlı yapıtı ise, izleyicisini doğrudan merkezine yerleştiren deneysel bir çalışmadır. 1952'de piyanist David Tudor tarafından ilk kez icra edilen bu yapıt, adını aldığ 4 dakika 33 saniye boyunca süren eylemsizlik/sessizlik durumunu konu edinmektedir. Piyanist Tudor'un icra ettiği bu yapıtta, piyanoya oturmak, notaları açmak, kronometreye basmak ve yeri geldiğinde sayfa çevirerek, önündeki boş ölçülerden oluşan notayı izlemek haricinde herhangi başka performatif bir öğe bulunmamaktadır. Böylece müzikal anlamdaki beklentilerin 
aksine 4 dakika 33 saniye boyunca süren bir boşluk sunulmuştur. İzleyicisini kendi sesleri ve tüm benliği ile baş başa bırakan yapıt, sanatçıyı ortadan kaldırarak bir yüzleşme alanı sağlamaktadır; yapıt aracılığıyla kişiye iade edilen bu 4 dakika 33 saniye aslında izleyicinin bireysel bütünlüğü ve değişen kişisel tepkileri gözlemlenmesi için ayrılmış bir süreyi temsil etmektedir. Her izleyiciye özgü olarak gerçekleşen yapıt sürekli yeniden oluşum ve devinim içindedir. Rauschenberg'in "Beyaz Resimler"inden ilhamla bu yapıtı bestelediğini ifade eden Cage (Cage, 2011, s. 192) ise konseri şöyle anlatır:

Dinlemeyi bilmedikleri için sessizlik diye düşündüler; her an rastgele seslerle doluydu. İlk bölümde dışardaki rüzgârın sesi duyuluyordu. İkinci bölüm sırasında çatıda yağmur damlaları pıtırdamaya başladı. Üçüncü bölümde de insanların konuşmaları ya da kalkıp çıkmaları bir yığın ses çıkardı. Gülmediler - hiçbir şey olmayacağını farkedince sinirlendiler, otuz yıl sonra bile hala unutmuş değiller, hala kızgınlar. Dostluğuna değer verdiğim arkadaşlarım vardı ve bu nedenden dostluklarını kaybettim. Yapmamış olduğum bir şeye müzik dememi bir tür kandırmaca olarak gördüler herhalde. (aktaran Fırıncıŏlu, 2011, s. 32)

Dada ve Duchamp'da dünyanın ve dolayısıyla sanatın içinde bulunduğu büyük bunalımla gerçekleştirdiği dönüşümün yanı sıra, öncelikle fotoğrafın sonrasında ise hareketli görüntünün icadıyla teknolojik gelişmeler de bir başka dönüşümü beraberinde getirmiştir. Bu bağlamda, sanatsal üretimi, estetik bakışı kökünden değiştiren ve alımlamaya yönelik kaçınılmaz farklılıklar yaratan teknolojik yenilikler yaşanmaktadır. Nitekim, "Tekniğin Olanaklarıyla Yeniden Üretilebildiği Cağda Sanat Yapıtı” adlı yazısında Walter Benjamin bu değişimi vurgulamış ve sanat yapıtının alımlanmasındaki değişime ilişkin birkaç noktanın altını çizmiştir. Bu noktalardan biri yapıtın "kült değeri” diğeri ise "sergileme değeri”dir. Benjamin’in burada vurgulamak istediği bir sanat yapıtının taşıdığı estetik değerin ne kadar paylaşılabildiği üzerinedir ${ }^{1}$. Teknolojik anlamda elde edilen imkanlar eskiye kıyasla hem daha kolay kamusallaşmakta hem de artık çokça insana aynı anda erişebilmektedir. Rönesans döneminde bir resmin ya da büstün karşılaştığı ile günümüzde bir sinema filmi karşısına geçen kitle arasında dramatik bir fark oluşmaktadır. Bu durum, kuşkusuz sanat yapıtının kamusal alana çıkması ve izleyicinin yapıta karşı takındığı tavır açısından oldukça önemli değişimler yaratmaktadır.

\section{Katılımcı Sanat Pratikleri}

Dada- Duchamp'ın ve teknolojilerin attığ 1 tohumlar, 20. yy'ın ikinci yarısından itibaren yeşermeye başlar ve ardından da meyvelerini verir. 1960'larla daha belirgin hale gelen izleyicinin varlığı artık sanatçının yapıtın yaratım sürecinin tek öznesi olmadığı fikrini de sağlamlaştırır. Postmodern süreç boyunca gördüğümüz birçok sanat anlayışı (yerleştirme, performans, arazi, süreç sanatları, oluşumlar vb.) izleyici ile birebir ilişkiyi önemser niteliktedir ve onu özgürleştirir. Burada Rancière'nin de belirttiği gibi özgürleşmeden kasıt, eylemde bulunan ile izleyenler arasındaki, birey ile kolektif bir yapının mensupları arasındaki sınırın belirsizleşmesidir. Mekânın ve zamanın, emeğin ve boş zamanın paylaşımının şimdi ve burada yeniden yapılandırılmasıdır (Rancière, 2009, s. 23-24). Bu yeni paradigma izleyici- yapıt- sanatçı üçgeninde yeni bir ilişkiselliğin doğmasına neden olmuştur. Sanatçının sarsılan otoritesi yerini kolektif bilinçle yeniden oluşturulan yapıta bırakmaktadır. Önceleri bakan göz'den ibaret tutulan izleyici, dahil olduğu bu yeni platformda duyular arası geçirgenlik göstermeye başlar. Öyle ki görmenin yanı sıra kimi zaman tatma, duyma, dokunma gibi duyular da yapıtın alımlanması için artık devrededir. Katılımcı sanat pratikleri aynı zamanda, Merzbau'nun başlattı̆̆ı bir izi takip etmiş, geleneksel sergileme yöntemlerini altüst ederek, sanatın kamusal alana çıkmasına vesile sağlamıştır. Böylelikle, modern paradigmanın "steril bir beyaz küp"e hapsettiği yapıt ve izleyici, zincirlerinden kurtulmuş ve kentin dolayısıyla hayatın tam da içine sızma imkânı yakalamıştır.

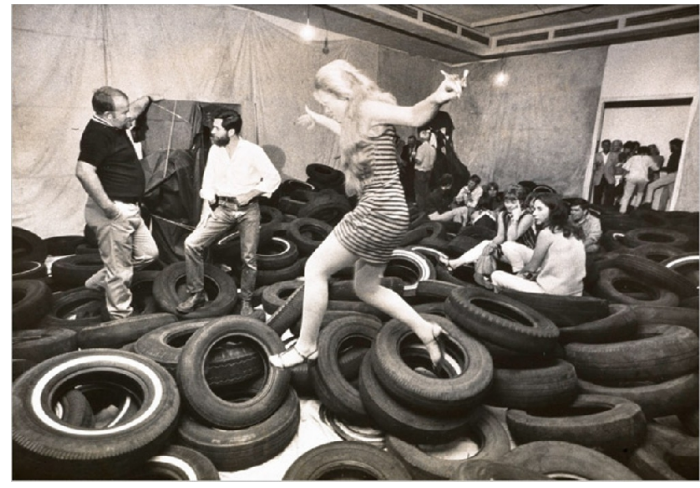

Görsel 3. Allan Kaprow, Tersane (Yard), 1961

\footnotetext{
${ }^{1}$ Detaylı bilgi için bakınız: Benjamin, W. (2007). Pasajlar. (A. Cemal, Çev.) İstanbul: Yapı Kredi Yayınları. s. 59-69-70
} 
Oluşumlar (Happenings) sanat yapıtlarının kamusal alana çıkması ve yeni bir deneyimselliğin yakalandığı öncül sanat etkinlikleri olmuştur. Galeri mekânının tek düzeliğinden yakasını kurtarmış bu etkinlikler, çok daha farklı mekanlarda gerçekleştirilerek izleyiciyi de kaçınılmaz olarak içine çekmektedir. Örneğin, Allan Kaprow’un, birçok oluşumunda gözlemlenebileceği gibi, Tersane (Yard) adlı 1961 tarihli mekân düzenlemesinde de katılımcıların bulundukları mekânda gezinmeleri yapıtın tamamlayıcı unsurudur. Birçok araba tekerleğinin yığılmış olduğu bu karmaşada Kaprow, izleyicinin engebeli koşullara rağmen yapıtın içinde gezinmesini ve çeşitli açılardan onu anlamlandırmasını talep etmektedir. Kaprow'a göre bu yapıt, bir oyun, bir macera, katılımcıların eğlenmek amaçlı katıldığı bir yığın aktiviteden oluşan sosyal bir eğlence alanıdır (Koven, 2014). Burada önemli olan, geleneksel metodların yıkılması ve bireylerin içinde gezindikleri yapıt aracılığıyla bir fiziksel aktivite gerçekleştirmesidir. Yapıtın içine çekilen ve kendi durağan konumunu yitiren bu yeni izleyici artık, eş üretici olarak yapıt üstünde yaptırıma sahiptir.

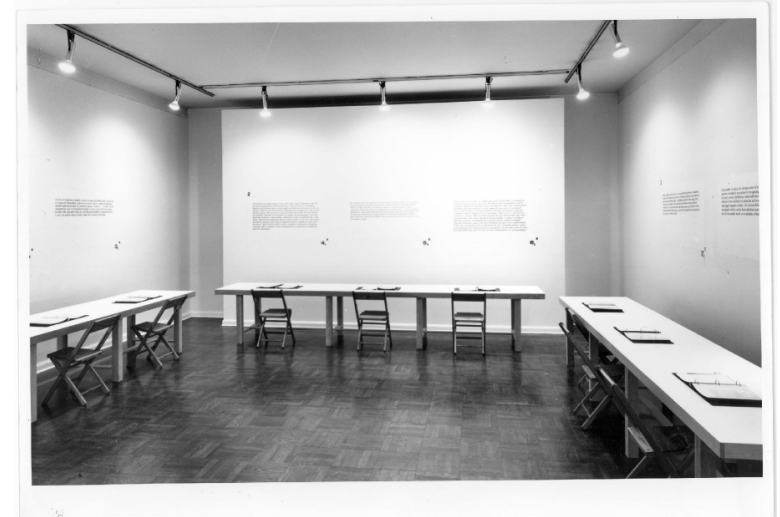

Görsel 4. Joseph Kosuth, 9. Sorgu (The Ninth Investigation), 1972

Joseph Kosuth 1972 yılında sergilemiş olduğu 9. Sorgu (The Ninth Investigation) adlı yapıtında, izleyicinin geleneksel durağan konumunu kendi akılcılığıyla sorgulamaya girişmektedir. Nitekim, bu yerleştirme izlemekten ziyade, içeriğinde bulunan kitapların okunma eylemiyle tamamlanmayı beklemektedir; bir çalışma odası havasında kurgulanmış bu yapıt, haklı olarak izleyicisinden bu çalışma eylemini gerçekleştirmesini arzulamaktadır. Kosuth'un bu yapıtı, bir beyaz küp yanılsaması içinde kalıpları bozan bir kırılma noktası yaratmıştır. Chris Burden'ın sansasyonel performansı Vurulma (Shoot)'da ise istemsizce bir olaya tanıklık eden izleyici çok daha farklı bir çelişkiye sürüklenmiştir. Menajeri tarafından sergi açılışı esnasında kolundan vurulan Burden, vuku bulan böylesi bir olay karşısında izleyicinin konumunu sorgulatmış, onları ne yapılması gerektiği konusunda ikircikli bir duruma sürüklemiştir. Gerçek hayatta böyle bir olay karşısında dehşete düşmüş vaziyette oraya buraya koşuşturan insanlar görmek şaşırtıcı olmayacaktır, fakat konu sanat olduğunda izleyici için durum daha kompleks bir olay haline dönüşmüştür.

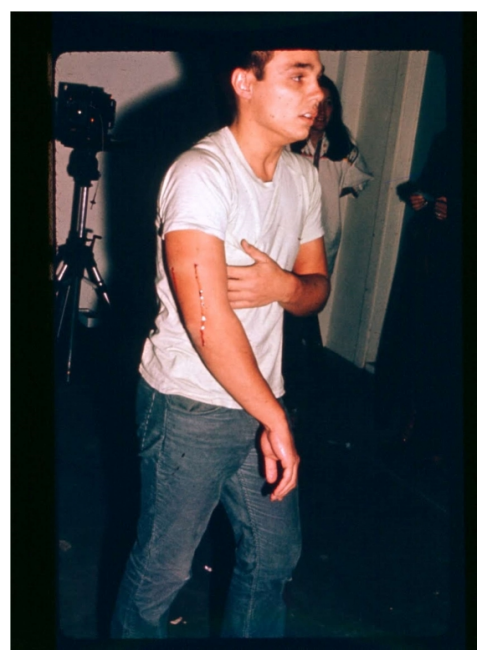

Görsel 5. Chris Burden, Vurulma (Shoot), 1971 


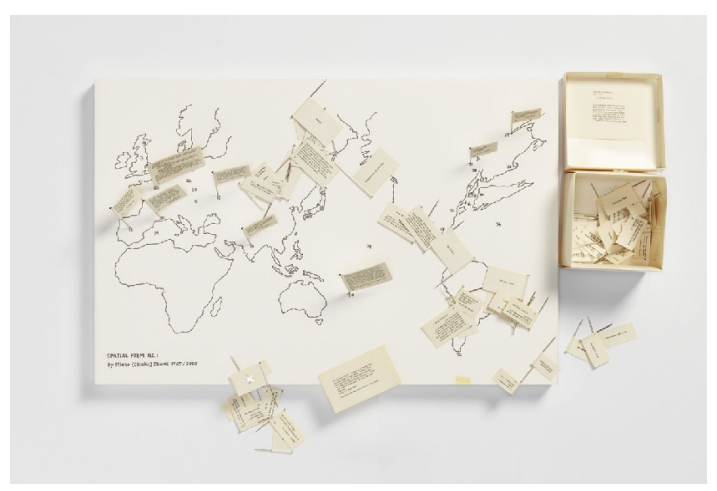

Görsel 6. Mieko Shiomi, Mekânsal Şiir 1 (Spatial Poems 1), 1965-75

Mieko Shiomi'nin Mekânsal Şiir (Spatial Poems) olarak adlandırdığı 1965-1975 yılları arasında 9 defa tekrarlamış olduğu hareketli şiirleri (action poems), Shiomi’nin dünyanın dört bir yanında coğrafi olarak konumlanmış tanıdıklarına e-posta yoluyla ulaşmasıyla başlar. Sanatçı bu gönderilerde katılımcılardan birtakım talimatları yerine getirmelerini ve gerçekleştirmiş oldukları etkinliklerden çeşitli objeler, haritalar, sözcükler biriktirerek ona ulaştırmalarını istemiştir. Birçok katılımcıdan edinmiş olduğu bu parçaları bir kitapta bir araya getirerek, sanatçı değil katılımcı odaklı bir yapıt ortaya koymuştur. Mekânsal Şiir kıtalararası iletişimin potansiyelini ve kolektif hareketin dönüştürdüğü ilişsisel performansı keşfetmek için bir girişimdir (Sanstone, 2014, s. 120). Aynı zamanda sanatın bireysel olan üretim gidişatında bir kırılma noktası yaratarak sanatçının yapıta olan müdahalesini minimum düzeyde tutmayı hedeflemektedir.

Valie Export'un 1968'te, Yoko Ono'nun 1965'te, Marina Abromoviç'in ise 1974'te gerçekleştirmiş olduğu katılımcı odaklı performansları izleyicinin konumunu radikalleștiren örneklerdendir. Export'un Elleme Sineması (Touch Cinema) olarak adlandırdığı performansı, sinemanın erkek hegamonyası altında bir araç olarak kadını metalaştırmasına yönelik bir eleştiri niteliğindedir. Bu bağlamda sanatçı katılımcılardan bedeninin göğüs bölgesine yerleştirmiş olduğu kare biçimli, televizyonu andıran, kutunun içine ellerini uzatmalarını talep etmektedir. Kutunun içine ellerini uzatan katılımcının içeride olanı dokunarak duyumlamasını, yani görme duyusu ile dokunma duyusunun yer değiştirmesini böylelikle görsel kültürün fetişleştirdiği şeylerin aksine dokunarak duyumsanan yeni bir durum önermektedir.

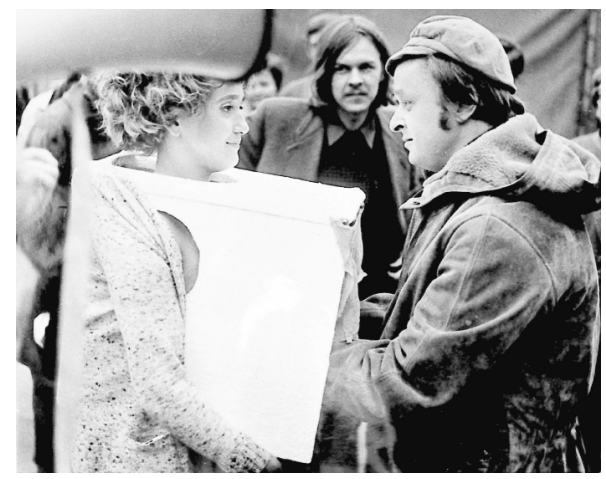

Görsel 7. Valie Export, Elleme Sineması (Touch Cinema), 1968

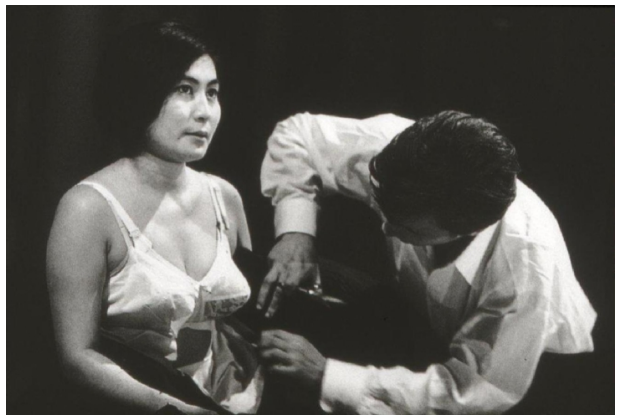

Görsel 8. Yoko Ono, Kesik Parçası (Cut Piece), interaktif performans, 1964 


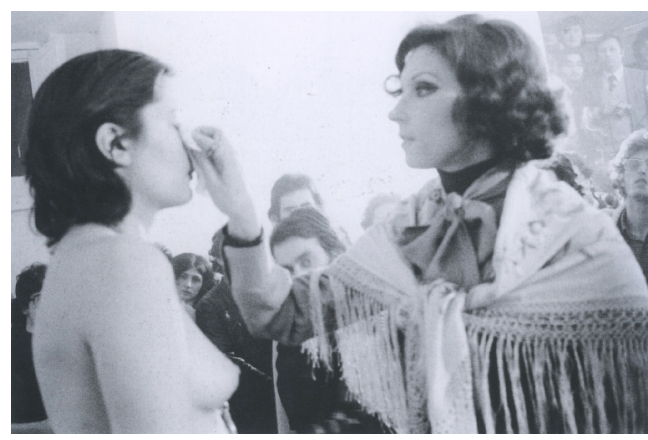

Görsel 9. Marina Abramoviç, Ritim 0 (Rythm 0), 1974

Yoko Ono'nun 1964'te ilkini gerçekleştirdiği Kesik Parçası (Cut Piece) çalışmasında bir sahneye oturarak, izleyicilerden bir makasla üzerindeki elbiseyi kesmelerini istemiştir. Ono'nun kadının edilgenleştirilmiş toplumsal rolüne ilişkin büründüğü bu pasif karakteri ve yaşanabilecek her olası şiddet eylemine karşı inisiyatifi üstüne alması oldukça çarpıcıdır. Bunun bir benzeri olan Abramoviç'in, Ritim 0 (Rhytm 0) çalışmasında da izleyiciye 72 farklı uygulama nesnesi verilerek limitler sorgulanmaktadır. Malzemelerin içinde gül, kuş tüyü ve balın yanı sıra, makas, neşter, bir tabanca ve tek bir kurşun gibi tehlike arz eden parçalar da bulunmaktadır. Katılımcılar, önce mütevazı ve utangaç hamlelerle başladıkları bu performansta bir süre sonra saldırganlaşmaya ve sanatçıya ciddi şekilde eziyet etmeye, zarar vermeye başlamıştır. Seyircinin ne kadar ileri gidebileceğini sorgulamak isteyen Abramoviç için ise bu durum, bir yanıt niteliği taşımaktadır.

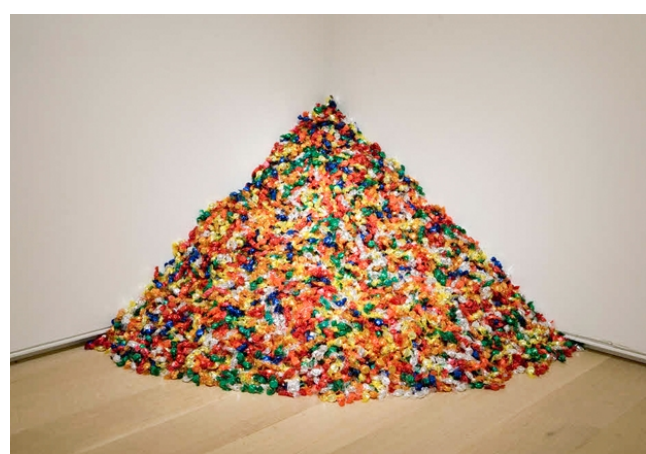

Görsel 10. Felix Gonzalez Torres, İsimsiz- Roos'un L.A'daki portresi (Untitled- Portrait of Ross in L.A.), 1991

Felix Gonzalez-Torres'in toplamda 19 farklı versiyonunu gerçekleștirdiği "şeker parçaları"ndan oluşan yapıtları, katılımcı sanat pratiklerinin önemli örneklerindendir. AIDS (kendisi de 1996'da bu hastalıktan vefat etmiştir) etrafında gezinen çeşitli konu başlıklarını hedef alan bu yapıtlar, kimi zaman hastalık boyunca alınan ilaçlara veya onların işlevsizliklerine (Placebo etkisi), kimi zaman da eșcinsellere karșı gerçekleștirilen keskin yaklaşımlara karşı eleştirel bir tutum barındırmaktadır. Sanatın doğası gereği politik olduğunu düşünen Torres (Torres, 1995), parlak kağıtlı şekerlerin göz kamaştırdığı dünyada, yaşamın gelip geçiciliğine vurgu yapmaktadır. Yığma ya da çeşitli minimal kompozisyonlarla sergilenen bu şekerler izleyiciler tarafından tüketilmek üzere mekânda sergi boyunca değişken bir biçimsel form kazanmaktadır. Azalan-tüketilen bu sanat yapıtı, insanın AIDS hastalığı nedeniyle günden güne nasıl yitirildiğinin de metaforik bir ifadesini ortaya koymaktadır. İzleyicisini yapıttan bir parça koparmaya iten bu yapıtlar, aynı zamanda izleyiciyi etik bir çelişki olarak şekerlerden almanın uygunluğu açısından da ikileme sürüklemektedir.

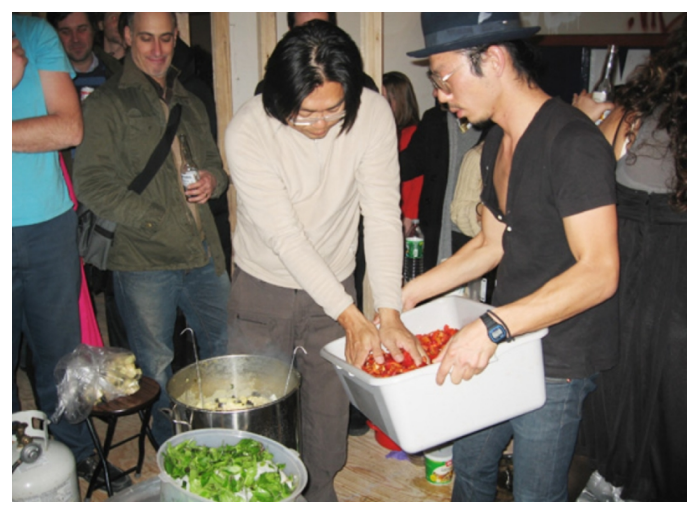

Görsel 11. Rirkrit Tiravanija, İsimsiz/Bedava (Untitled/Free), 1992-1995-2007-2011 
Batı'nın estetik objeye olan ve onu sürekli tüketen bakışına karşı duran (Birnbaum ve Tiravanija, 2015, s. 164) Rirkrit Tiravanija, yeme seanslarında bu tüketimi farklı bir boyuta çıkarmaktadır. Yemeğin günlük olarak herkes tarafından tüketilmesini lehine kullanan sanatçı, sergi için ayrılmış bir mekânı kendi mutfağına çevirerek izleyicisine yemek pişirmekte ve bu süreç boyunca galeri mekânını işlevinden koparmaktadır. Thai yemeğinin egzotik ve sınırda kalan yapısından da faydalanan Tiravanija, sanat yoluyla açmış olduğu bu paylaşım ağıyla kolektif bir beraberlik yaratmaktadır. Birbirini tanımayan kişilerin yemek vesilesiyle etkileşime geçtiği bu serbest alan katılımcı girişimler için oldukça verimli olurken, sanatçıyı da diğer birçok örnekte olduğu gibi görünmez bir forma sürüklemektedir.

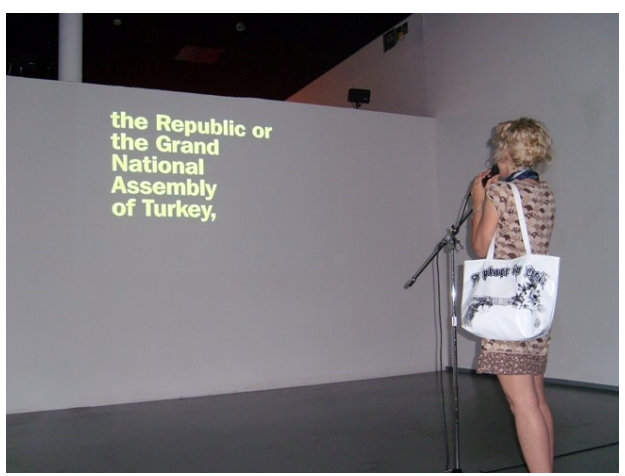

Görsel 12. Ferhat Özgür, Seni Seviyorum 301 (I Love You 301), 2008

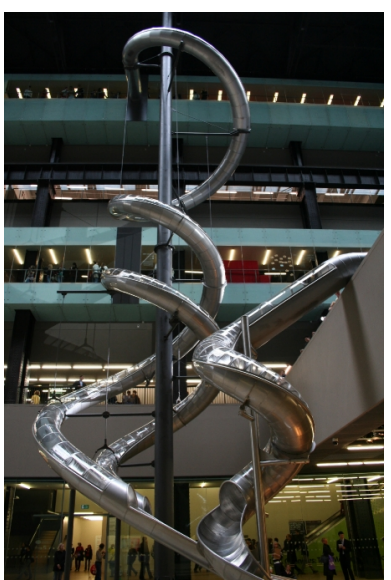

Görsel 13. Carsten Höller, Test Sahası (Test Site), 2006

İzleyicisiyle ilişkisel bir yapı oluşturan yapıtlardan bir diğeri, Ferhat Özgür'ün 2008 yılında gerçekleştirmiş olduğu katılımc1 yerleştirmesi Seni Seviyorum 301 (I Love you 301)'dir. Türk Ceza Kanunu'ndaki 301. maddeyi bir aşk şarkısı olarak kurgulayan Özgür, izleyicilerin bu şarkıyla karaoke yapmasını kurgulamıştır. Yasal olarak bireylerin uymak durumunda olduğu bu maddenin otoriter yapısını karaokenin eğlendirici havasına büründüren bu yapit çeşitli noktalara gönderme yapmaktadır. Carsten Höller'in Test Sahası (Test Site) adlı yapıtı ise ilişkisel bir oyun barındıran diğer bir örnektir. Tate Modern Müzesi'nin farklı katlarına kayarak gitmeyi sağlayan bu yerleştirme, aynı zamanda büyükçe bir alana sahip olan müzede yer değiştirmeyi kolaylaştıran bir sanat formudur. Burada işlevsel özelliğinin yanı sıra oyun etkinliğini de içinde barındıran kaydıraklar, bir eğlence parkında çocukların neşeyle bindiği kaydıraklardan farksız durmaktadır.

\subsection{Güncel Tartışmalar}

Öncül örneklerin gittikçe arttırdığı ivme ve fenomenoloji-hermeneutik tartışmalarının ilişkisellik üzerine geliştirdiği yeni okumalar, katılımcı sanat pratiklerinin daha da yaygınlaşmasına uygun ortamı hazırlamıştır. Sanatta ilişkisellik üzerine oluşturulan metinler, "İlişkisel”" veya "alımlama" estetiği gibi başlıklarla, izleyicinin kendi konumuna dair yeni bir farkındalık oluşturması açısından oldukça önemlidir. Örneğin, Nicolas Bourriaud'nın Iliş̧kisel Estetik adlı kitabı söz konusu bu katılımcı sanat anlayışını ve izleyicinin yeniden konumlanmasına detaylı bir biçimde ele alan önemli çalışmalardan biridir. Bourriaud'a (2005) göre, tüm bu tüketim kültürünün yarattığı şeyleşmeden bir ölçüde korunmuş tek alan sanatsal uygulama alanıdır. Çünkü sanat, yaşadığı çağa göre değişim-evrim geçirebilen bir oyundur. Tekbiçimlikten korunmuş sanat alanı sayesinde, dünyaya kalıcı bir iz bırakma gibi kompleksli insan öznelliğinden sıyrılan ve sınırsız tartışmaya yönelik bir açılım kendini göstermektedir. İlişkisel bir sanat karşılıkl1-eylemleri ve bunun toplumsal içeriğini barındırmakta, modern sanatın ortaya attığı estetik, kültürel ve siyasal amaçları kökünden sarsmaktadır (s. 22). 
Bourriaud'a göre güncel sanatçının amacı, anın sunduğu her türlü koşulu yaşarken algılanabilir ya da kavranabilir dünya geçekliğini sanat yoluyla kalıcı bir hale büründürmekten öte değildir. Bu bağlamda ilişkisel sanat, kendi halinde özerk bir uzamı ifade etmek yerine, karşılıklı eylemler içeren yeni bir alan oluşturmalıdır; şeylerin metalaştığı bu düzende ticari tüm niteliklerinden sıyrılmalı; makineleşmenin getirdiği tüm yozlaşmaya karşı bir insani ilişkiler uzamı oluşturmalıdır. Estetik bir şeye dönüşme aynı zamanda tüketilecek bir metaya dönüşme riskini içinde barındırdığ 1 için kolektif sanat pratiklerinin amacına ters düşmektedir. Bu düşünceyi vurgulayan Bishop sanatın, piyasa için meta tedarik etmek yerine, sembolik sermayeyi yapıcı toplumsal değişime yönelten bir şey olduğunu savunmaktadır (Bishop, 2018, s. 21). Bireysel üretim alanından uzaklaşan sanatçının giderek her süreci izleyicisine açması ve böylelikle sistemin insanları durmadan ayrıştırdığı bir gerçeklik içinde birleştirici bir unsur olarak sanatın rol oynaması oldukça kıymetlidir. Buluşmalar, oyunlar, bayramlar, toplantılar, festivaller, kısacası insanların bir araya gelmesini sağlayan her türlü vesileyi yaratan sanat yapıtları, bu bağlamda çağın estetik birer formu olarak karşımıza çıkmaktadır. Sanat yapıtının bu zamana kadar belli estetik değerlere bağlı olarak üretilmesine kıyasla, toplumsala açılan bu yeni kapı ile muğlaklaşan bu değerler, yeni bir estetik algının geliştirilmesini kaçınılmaz kılmıştır.

Sanat yapıtının bu denli geniş bir çerçevede ele alınması, forma veya sınırlılıklara dair belirsiz bir biçimde cereyan etmesi, estetik anlamda güncel bir tartışma alanı yaratııştır. Katılımcı sanat örnekleri doğrudan olmasa da dolaylı olarak genel sanat anlayışına bir başkaldırıdır ve geleneksel sergileme, üretim ve değerlendirme biçimlerini bozan bir özelliği vardır. Bu noktada ilişkisel sanat örneklerinin döneminin öncülü olarak çeşitli kalıplar altına sokulmaması önemlidir. İlişkisel sanatın girdiği estetik çelişkiyi Estetiğin Huzursuzluğu adlı kitabında tartışan Rancière'e (2012) göre, estetik bir disiplinin değil, sanatı tanımlamaya yönelik özgül bir rejimin adıdır. Bu bağlamda sanat, insanın kaybettiği doğayı (sensorium) yansıtmalıdır; "duyusallık" ile "etkin zekâ" kıyasıya bir rekabet içinde değil, bir doğanın eş iki parçası olarak özgürce karşılaşmalıdır; sanatçının değil, halkın dehasına gönderme yapmalı, verili olan dünyanın nesnelerini ve imgelerini tekrar düzenleyen bir itki olmalıdır. Sıradan hayatın pek de berisinde olmayan ve eleştirel ya da suçlayıcı değil, daha ziyade ironik ve oyunsu bir kipte sunulan bu mikro-durumlar, bireyler arasında bağlar yaratma ya da yeniden yaratma, yeni yüzleşme ve katılım tarzları doğurma hedefini taşımaktadır (s. 14-25). Yani sanat, tüm sürecin ayrıştırdığı dinamikleri ve en başta insanları bir araya getirecek mekân-ortam yaratma hususunda tarihsel bir misyon edinmiştir.

Kişileri bir araya getirme hususunda önemli örneklerden olan Oda projesi, 2000 yılından bu yana Özge Açıkkol, Güneş Savaş ve Seçil Yersel'in sürdürdüğü, çeşitli sanat etkinlikleriyle katılımcıları teşvik etmektedir. 2005 yılına kadar İstanbul Galata'da yer alan mekanlarında birçok kolektif çalışmaya ev sahipliği yapan proje, sonrasındaki süreçte daha bağımsız bir hal alarak varlığını devam ettirmiştir. İstanbul'da hem kentin hem de sanatın belleğini tutan Oda Projesi, katılımı merkeze alan etkinlikleri ile çeşitli platformlar yaratmaktadır. Benzer bir örnek Ankara'daki oluşumlardan Torun için de geçerlidir. 2012'de çeşitli disiplinlerden sanatçıların bir araya gelerek kurduğu bu oluşum, bünyesine sadece sanatla değil birçok farklı disiplinden ve meslekten insanı katarak kolektif bir varlık sergilemiştir. Gönüllülük esaslı olarak herkese kapısını açan inisiyatif, sergiler, film gösterimleri, workshoplar ve konuşmalar düzenleyerek Ankara'daki durağan ortama katkı sağlamakta ve bireyleri kolektif bir çatı altında toplamaktadır. Halen yazılı kaynaklar ve çeşitli etkinliklerle varlığını devam ettiren inisiyatifin en önemli özelliği ise içerisinde yer alan kişilerin isimsiz olarak etkinlikleri başarabilme kabiliyetidir. Kuşkusuz, isimlerin ve unvanların böylesine önemsendiği bir ortamda bunu başarabilmek oldukça önemli görünmektedir.

\section{Sonuç}

Dada ile kristalleşen kuralsız-melez sanat anlayışı, modern sanatın mihenk taşı olan "biricik- özgün" yapıt anlayışında kırılmalar yaratmıştır. Bu kırılmayla birlikte geleneksel sanat anlayışı ters yüz edilmiş; sanat, Kantçı yüce estetiğin katı kurallarından arındırılarak, hayat ile sınırları tartışmaya açılmıştır. Sanatçının yapıt üzerindeki mutlak iktidarının sorgulandığ postmodern dönemle birlikte eyleyen konuma erişen ve bu bağlamda sanatsal üretimin kimi zaman doğrudan ortağı haline gelen izleyicinin söz konusu konumu 1990'larda başlı başına bir sanat biçimine dönüşmüştür. Illişkisel Estetik gibi ortaya çıkan kuramların da bel kemiğini oluşturan ve “izleyici”sini işin içine birçok yöntemle dahil eden bu pratikler kolektif bilince vurgu yapmakta, aslında ayrılmaz bir ilişkiyi diğer bir deyişle ilişkiselliği ön plana çıkarmaktadır.

Her insan bedeninin bir mübadele nesnesine dönüştürüldüğü böylesi bir düzende öteki-beriki olarak ayrıştırılmakta, yalnızlaştırılmaktayız. Sosyal bir canlı olduğumuzu neredeyse tamamen unutmuş durumdayız ve yalnızlığın bir tür özgürlük yanılsamasına dönüştüğü mevcut düzlemde, tek başına ayakta durabildiğimiz için kendimizi sürekli kutluyoruz. Kolektif yaşamın insana içkinliğini ve ilkel kabilelerin hayatta kalmasının en önemli sebebinin bu biraradalıktan kaynaklandığını görmezden geliyor ve şeyler düzeninin kaçınılmaz birer parçası olarak sisteme sürekli hizmet ediyoruz. Katılımcı sanat pratikleri en başta bu ayrıştırmayı aşındırmak, bireyler için çeşitli ön eklerden ve sosyal sınıflarından sıyrılabilmek, yaşamsal kontrastları yok etmek adına oldukça önemli bir süreci içinde barındırmaktadır. Bu bağlamda, bireyler olarak değil kalabalık gruplar olarak bir şeyler gerçekleştirme becerisini sanat pratikleri aracılığıyla başarmak, ilkel bir ritüel gibi, yaşamsal bir yüzleşme alanı yaratmaktadır. 
“İletişim” çağında olmanın yarattığı bir iç çelişki olarak insani temaslardan gittikçe yoksunlaşmaktayız. Toplumsal bağların kopma noktasına geldiği böylesi bir düzlemde ilişkisel sanat, mütevazi dallar, bireylerarası geçitler yaratmakta ve kaybolan doğaya ilişkin bazı hatırlatmalarda bulunmaktadır. Katılımcı pratikler, insanın bu kayıp doğasına atıfta bulunurken, bir yandan da kapitalizmin süreçten ziyade ürüne odaklanan yapısını kuşatmakta, ürünün önemsizleştiği bir ortam oluşturarak, sürecin benimsendiği yeni bir deneyim yaratmaktadır. Kuşkusuz bu durum, yaşamsal dizgeyi kırmak açısından da oldukça önemlidir.

Sanat yapıtının ilişkisel boyutta ele avuca sığmaz hali onu bir oyun ya da deney sahasına çevirmiştir. Geleneksel üretim dizgesinde sanatçının büyük yalnızlığına el koyup, sosyal içerikli ve merkezsiz bir sanat oluşturma fikri katılımı merkezine yerleştiren çok çeşitli türler yaratmıştır: Diyalojik sanat, littoral sanat, müdahaleci sanat, işbirliğine dayalı sanat, interaktif sanat, ilişkisel sanat adına her ne denirse, artık sosyal bir pratik olarak sanat gündemdedir. Tiravanija'nın yemekleri, Özgür'ün uzattığı mikrofon, Ono'nun seyircinin eline tutuşturduğu makas, Carsten Höller'in izleyicisini yutan kaydırağı, Shiomi'nin e-postaları çağdaş sanat yapıtının birleştirici gücünü lehimleyen araçlardır ve burada önemle vurgu yapılan, sanatın insan ile olan kopmaz bağlantısıdır.

\section{Kaynakça}

Benjamin, W. (2007). Pasajlar. (A. Cemal, Çev.). İstanbul: Yapı Kredi Yayınları.

Birnbaum, D., \& Tiravanija, R. (2015). Rirkrit Tiravanija: Meaning is use. Log, 34, 163-170. Erişim adresi: http:// www.jstor.org/stable/43630936

Bishop, C. (2018). Yapay cehennemler: Katılımcı sanat ve izleyici politikası. (M. Haydaroğlu, Çev.). İstanbul: Koç Üniversitesi Yayınları.

Bourriaud, N. (2005). İlişkisel estetik. (S. Özen, Çev.). İstanbul: Bağlam Yayınları.

Cage, J. (2011). Seçme Yazılar. (S. Fırıncıoğlu, Haz. ve Çev.). İstanbul: Pan Yayıncılık.

Eco, U. (1992). Açık yapıtın poetikası. (Y. Şahan, Çev.). İstanbul: Kabalcı Yayınevi.

Fırıncıoğlu, S. (2011). Giriş yazısı. J. Cage, Seçme Yazılar (s. 1) içinde. İstanbul: Pay Yayıncılık.

Koven, B. L. (2014). D.I.T. Erişim adresi: https://www.aplayfulpath.com/do-it-together/

Kuspit, D. (2010). Sanatın sonu. (Y. Tezgiden, Çev.). İstanbul: Metis Yayınları.

O'Doherty, B. (2013). Beyaz küpün içinde: Galeri mekanının ideolojisi. (A. Antmen, Çev.). İstanbul: Sel Yayıncilık.

Rancière, J. (2009). Özgürleşen seyirci. (E. B. Şaman, Çev.). İstanbul: Metis Yayınları.

Rancière, J. (2012). Estetiğin Huzursuzluğu: Sanat Rejimi ve Politika. (A. U. Kılıç, Çev.) İstanbul: İletişim Yayınlar1.

Sanstone, J. (2014). Archiving fluxus performances in Mieko Shiomi's spatial poem. C. Townsend, A. Trott, \& R. Davies (Ed.), Across the great divide: Modernism's intermedialities, from futurism to fluxus (s. 120-136) içinde. Newcastle: Cambridge Scholars Publishing.

Torres, F. G. (1995, January). Etre un espion. 24-32. (R. Storr, Röportaj Yapan) ArtPress.

Türk Dil Kurumu. (t. y.). İzleyici. Erişim adresi: https://sozluk.gov.tr/

\section{Görsel Kaynakçası}

Görsel 1. Art \& Education, (2020), Our vision for the art domain, the issues involved, and what is at stake for the art community, Marcel Duchamp'ın yapıtına ait görsel. Erişim adresi: http://ebys.ahbv.edu.tr/enVision/ Portal.aspx

Görsel 2. Inside Out, (2012), In Search of Lost Art: Kurt Schwitters’s Merzbau. Erişim adresi: https://www.moma. org/explore/inside_out/2012/07/09/in-search-of-lost-art-kurt-schwitterss-merzbau/

Görsel 3. Happenings - nedir bu? Sanatta örnekler, (2020), Erişim adresi: https://tr.deborahnormansoprano.com/ iskusstvo-i-razvlecheniya/48956-heppening-eto-chto-takoe-primery-v-iskusstve.html

Görsel 4. Castelli, (2020), Joseph Kosuth The Ninth Investigation, Proposition One. Erişim adresi: https://www. castelligallery.com/exhibitions/joseph-kosuth16

Görsel 5. The Art History, (2020), Amerıcan Sculptor And Performance Artist. Erişim adresi: https://www. theartstory.org/artist/burden-chris/

Görsel 6. MoMa Sanatçı Koleksiyonu, (2020), Erişim adresi: https://www.moma.org/collection/works/127563 
Görsel 7. Valie Export Yapıt Görseli, (2020), Erişim adresi: https://www.valieexport.at/jart/prj3/valie_export_ $\mathrm{web} /$ main.jart?rel=de\&reserve-mode $=$ active\&content-id $=1526555820281 \& \mathrm{tt}$ news_id=1956

Görsel 8. Moma Learning, (2020), Erişim adresi: https://www.moma.org/learn/moma_learning/yoko-ono-cutpiece-1964/

Görsel 9. Ekşişeyler, (2017), Vücudunun ve Seyircinin Sınırlarını Görmek İsteyen M. Abramovic'in Unutulmaz Performans1: Rhythm 0. Erişim adresi: https://seyler.eksisozluk.com/vucudunun-ve-seyircinin-sinirlarinigormek-isteyen-m-abramovicin-unutulmaz-performansi-rhythm-0

Görsel 10. Milliyet Sanat, (2015), "Untitled" (Portrait of Ross in L.A.). Erişim adresi: http://www.milliyetsanat. com/haberler/plastik-sanatlar/-untitled-portrait-of-ross-in-l-a-/5665

Görsel 11. Pairings: Installation Art \& Architecture, (2015), Erişim adresi: https://pairings.weebly.com/pairingsinstallation-art--architecture/pairing-rirkrit-tiravanija-and-the-way-things-go

Görsel 12. Cargocollective (2020), Erişim adresi: https://payload.cargocollective.com/1/13/434137/6855925/ MILANO_2008\%20009.jpg

Görsel 13. Tate, (2007), Art of Interaction: A Theoretical Examination of Carsten Höller's Test Site. Erişim adresi: https://www.tate.org.uk/research/publications/tate-papers/15/art-of-interaction-a-theoretical-examination-ofcarsten-holler-test-site 